\title{
IMPACT OF WORKLOAD INDUCED STRESS ON THE PROFESSIONAL EFFECTIVENESS OF SECONDARY SCHOOL TEACHERS IN CROSS RIVER STATE
}

MELVINA AMALU

(Received 10, May 2013; Revision Accepted 19, August 2013)

\begin{abstract}
The study was aimed at determining the impact of stress from workload on professional effectiveness of secondary school teachers in Cross River State, Nigeria. The ex post facto design was used in a survey of 600 public secondary school teachers. Result of the data analyses indicated that stress from workload has no significant influence on seven dimensions (lesson presentation, use of instructional aids, evaluation of students, learning motivation, classroom management, supervision of co-curricular activities and personal/professional qualities) of professional effectiveness. Based on the data recommendations were made on how management of organization should tackle the issue of workload.
\end{abstract}

KEYWORDS; Stress, Workload, Professional effectiveness, Teachers, Cross River State

\section{INTRODUCTION}

Education according to Obanya(2013) is not simply concerned with "knowing Book" but more concerned with helping an individual grow, in the sense of all-round development and positive change. It is vital for equipping individuals with the right quality of knowledge, skills, competencies, values and attitudes to enable them function competitively in emerging e- driven society( Okute and Chukwurah:2011).To achieve the objective of Education as spelt out in the National Policy on Education of the Republic of Nigeria, the Educators must combine effectiveness with quality to bring out the desired outcome. This implies that the right quality and quantity of teachers, equipment/facilities, incentives and adequate funding must be provided .It also requires commitment on the part of teachers and managers of educational resources. In his work on commitment of teachers Isangedighi (2000) advised that the teacher should be committed to his duties by enforcing rules and regulations put in place to ensure the right climate for effective learning and teaching. He argued that where commitment is lacking, the productivity of the individual is lowered.

Stress according to Martin; Carlson and Buskist (2007) is a pattern of physiological, behavioral and cognitive responses to stimuli (real or imagined) that are perceived as endangering one's well-being. They went further to state that prolonged stress can produce anxiety which may impair one's ability to perform a task. It implies that any teacher experiencing high level of stress may break down, feel vaguely weak, tense, restless slow, generally tired, may become too sick to work, quit work or refuse to work any further. In other words, stress can inflict low productivity Denga: 1991)

The teacher is a trained professional with knowledge and skill, as well as a level of competence in the task of teaching and remolding the children under his care. The teacher is expected to teach his students, evaluate them, maintain discipline, counsel and advise them. He is expected to motivate the students to learn and help them mature into responsible adults. Evidently, some teachers are non-challant and less committed in the discharge of their duties. For example, in some schools, many teachers go to school late, teach the

Melvina Amalu, Department of Educational Foundation, Guidance and counseling, University of Calabar, Calabar, Cross River State, Nigeria. 
students sparingly, rarely conduct tests and when tests are given, some take too long a time to do the marking. Some teachers hardly help in supervising co-curricular activities in schools. Commenting on poor state of public education in Cross River State, Bisong (1996) noted that some teachers in secondary schools spend little or no time to prepare their improvisation is something nobody wants to talk about. In Cross River State, Despite the seeming improvement of teachers' salaries, one continues to observe truancy, lack of dedication to duty and declining productivity (Bassey; Bisong: Ubi \& Isangedighi: 2011) According to Amalu; Ajake \& Isangedighi (2012), some teachers hardly evaluate their lessons or encourage students to participate in classroom learning. Such teachers never entertain questions in class nor praise students who answer questions rightly. In some schools students are hardly ever given enough attention, individual differences are neglected, while continuous assessment suffers (Amalu: 2012). In their role performance, some teachers do not seem to exert themselves adequately, so it is also common to see student loitering about inside their school compounds and even nearby streets when they are supposed to be in their classes for lessons. Teachers' professional ineffectiveness and their consequences do not however pass unattended to For example, the secondary school education Board has tried to push teachers to improve upon their present level by seeing to it that principal provide time books in their schools for teachers to indicate the time they report for work and also sign off when leaving the school. This is to help check lateness to school and lack of seriousness in role performance. In order to encourage teachers to be effective and stay on the job, Government of Cross River State had approved allowances for science teachers, as well as some incentives for teachers whose students perform well in Secondary School Certificate Examination (SSCE).These apart, efforts are on-going to ensure that salaries are paid promptly.

Despite all these efforts and other good gestures by State Secondary School Board State Government, School Principals, Parents, Educationists, even teachers themselves complain about teachers' lack of dedication to duty. In consequence, poor academic performance of students has remained a recurrent issue

\section{Literature review}

Workload according to Stickler (2000) is the sum of all activities that take the time of an employee. Workload can at times be heavy(overload or light (under load).Debra (1995) sees role overload as a situation in which employees feel they are being asked to do more than time or ability permits. He further stated that working under time pressure can be stressful because people are anxious when they have a lot to do before some deadline, as time runs out a feeling of impending disaster increases.

Wakefield (1983) in his work stated that role under load is a condition in which employees have too little work to do or too little variety in their work. Role under load he further emphasized can lead to passivity, low selfesteem, increased frequency of nervous symptoms and complaint, lack of interest in social activity and work performance output. Marshall (1993) conducted a research aimed at determining the relationship between workload and leadership effectiveness. The result however, showed that workload has a significant influence on leadership effectiveness. In another study conducted by Fadipe (1970) to assess the influence of workload on leadership effectiveness of head of department in a paper mill found out that executives with excess workload gave in so much of their time to meet up with deadline at the expense of their leisure and this according to Denga (1996) attract psychosomatic debilities. Once a worker has over indulged in occupational pursuit, he suffers from occupational stress which can lead to decline in his job performance.

Teachers' effectiveness is positively influenced by having too much to do or having to tackle too difficult work .Denga and Ekpo (1994) found out that overload whether quantitative or qualitative may lead to stress and concomitant gross ineffectiveness. Orjiji (2000) identified work overload and under load of job as factors that can generate feeling of hopelessness and also may contribute towards lack of motivation, depression and inefficiency. In their separate studies, Bryan and Kelly (1984); Burry and Philip (1991); Seigenthaler (1997) found out that role overload and role under load do significantly influence workers, job performance. Ekpo (1993) stipulated that an executive who does not want to delegate powers and responsibilities to subordinates for mere fear that mistakes might be made and decides to do almost everything may get himself overloaded with work and this may lead to the exhibition of inertia, inefficiency, incompetence and a high level of stress. Yet as reported by Harbegar and Lohrs(1984) When an executive is stressed up as a result of work overload, becomes moody, emotionally unstable, 
experiences lowered self esteem, resentment of supervision, indecision, job dissatisfaction and un productivity.

In the research on secondary school teachers' workload in New Zealand, Australian Council For Educational Research ACER(2004) found out that mainly the managers were clearly the group most affected by workload, largely related to their responsibilities .Arnold and Feldman (1986) noted that prioritizing tasks of teachers using support staff for non professional duties, minimizing the number of meetings and using the meeting time for effectively time tabling blocking of time for teachers to meet, filtering the demands of outside agencies, capacity- building, providing teachers with knowledge and skill they needed to work as competent professionals, lighten workload and increases job satisfaction and work effectiveness.

\section{Statement of problem}

According to Ivowi (1986) a teacher needs to demonstrate efficiency in his primary role of transmission of skill and knowledge because his role is very vital in shaping the life and quality of marketable skill development of individual in stimulating and sustaining the economic activities of the nation. But over the years there have been a great concern in Nigeria over the effectiveness with which teachers' carryout their duties. The public seem to have lost confidence in the school system as the professional inadequacies exhibited by the teachers have been questioned. Parents and government agencies are worried over the failure rate of students especially in internal and external examination. In an attempt to improve this the Government in recent times has increased its funding to schools, improved on its physical facilities, equipped laboratories and libraries to an extent, increased teachers allowances and recruited and redeployed some trained teachers to schools. Despite all the attempts, job performance of teachers generally continues to dwindle and poor academic performance of students has remained a recurrent issue in our educational system. This situation is what has motivated this study which is aimed at determining if stress from workload could be explanation and for the professional ineffectiveness of secondary school teachers in Cross River State.

\section{Purpose of the study}

The purpose of the study is to determine the influence of stress from workload on professional effectiveness of secondary school teachers

\section{Hypothesis}

Stress arising from workload has no significant influence on professional effectiveness of teachers vis-a-vis lesson presentation, use of instructional aids, classroom management, Evaluation of students, learning motivation, supervision of co-curricular activities, professional and personal qualities.

\section{Significance of the study}

To the teachers, this study will point their weaknesses and strength and proffer ways of overcoming these pitfalls. It may stimulate interest in professional effectiveness through focusing on the various dimensions of teachers' effectiveness and how each dimension contributes to the overall teacher effectiveness. Teachers will also appreciate students feeling and assessment of teachers' performance and try to improve.

The study will also enable the teachers realize that no individual can fulfill all role expectations simultaneously and that trying to do that may lead to overload of work and subsequent low performance.

The result of this study will enable educational planners, policymakers to formulate educational policy that will enhance job effectiveness. It will also create awareness in the students of the problems faced by their teachers in all the dimensions of teaching effectiveness. This could create a desire in the students to be part of the solution not part of the problem.

Most of the studies conducted in the area of stress from workload drew their data from organizational setting. In this study the focus was on the secondary schools. For the researcher, the study shall help to ascertain and clarify whether the findings of earlier studies on related issues can be generalized to all categories of workers.

Lastly, the study will also significantly contribute to academic literature in education and social psychology. Similarities may exist between the findings of this study and earlier studies and it is hoped that this will spur the interest of other researchers

\section{Sample and sampling technique}

60 schools out of 230 public secondary schools, 600 teachers out of 1008 teachers teaching senior secondary two(SS11) students and 2400 SS11 students out of 15646 students were selected using simple and stratified random technique. Stratified random sampling was used in grouping the secondary schools into three 
educational zones namely Calabar, Ikom, and Ogoja. Simple random sampling was then used to select a sample of six hundred(600) teachers and two thousand, four hundred (2400) SSII students from 60 secondary schools.

\section{Data collection}

The research data were collected through the use of self administered questionnaire titled: Occupational Stress Inventory (OSI). The questionnaire which was constructed by the researcher had two sections. Section A elicited from the respondent demographic information such as sex, age, highest educational qualification, marital status, year of teaching experience and their area of specialization. Section B was designed to measure pattern of stress arising from workload. It consisted of 20 item Likert- type scale(such as teaching load, preparing lesson note, supervising manual labour etc)with 4 alternative responses( Very stressful, stressful, little stressful and not stressful). The instrument had a reliability index of 0.73 Copies of the instrument were administered to the subjects in their respective schools. Of the 630 copies of the questionnaire given out only 600 were fully completed and returned. Information from the 600 respondents was used for data analysis. Regarding teacher job effectiveness, each teacher was assessed by four of his/her students. The average score of the four assessors was used as a measure of the teachers teaching effectiveness. The scale used in assessing teachers' job effectiveness was a 28 item likert-type scale and subunits considered included lesson presentation, use of instructional aids, evaluation of students. Learning motivation, supervision of co-curricular activities and professional/personal qualities. The teacher effectiveness scale had a reliability index of 0.93

\section{DATA ANALYSIS}

Analysis of variance(ANOVA) statistics was used in testing the hypothesis at 0.05 level of significance

\section{RESULT}

Table 1 shows the mean and standard deviation. While Table 2 shows the actual results of ANOVA. As presented in Table 2, the result of the data analysis shows that the calculated Fvalue of 1.64(for lesson presentation), 0.94 (for use of instructional aids, ) 0.85 (for classroom management), 1.04 (for evaluation of students), 0.47 (for learning motivation), 0.41 (for supervision of curricular activities)and 0.31 (for professional/personal qualities) are less than the critical F-value of 3.00 at 0.05 level of significance with 2 and 597 degree of freedom. With these results, the null hypothesis is accepted in each of seven instances studied. It implies that stress arising from workload has no significant influence on the way and manner the secondary teachers performs their professional roles. 
Table 1: Group Means and Standard Deviations on respondent based on the impact on the levels of workload on professional effectiveness of teachers.

\begin{tabular}{|c|c|c|c|c|c|}
\hline S/No & Professional effectiveness & level of stress & $\mathrm{N}$ & Mean & SD \\
\hline \multirow[t]{4}{*}{1.} & Lesson presentation & Low & 185 & 8.80 & 1.10 \\
\hline & & Moderate & 258 & 10.74 & 2.50 \\
\hline & & High & 257 & 10.579 & 2.29 \\
\hline & & Total & 600 & 10.579 & 2.31 \\
\hline \multirow[t]{4}{*}{2.} & Use of Instructional aids & Low & 185 & 9.80 & 0.84 \\
\hline & & Moderate & 258 & 10.17 & 1.61 \\
\hline & & High & 157 & 10.13 & 1.90 \\
\hline & & Total & 600 & 10.128 & 1.87 \\
\hline \multirow[t]{4}{*}{3.} & Classroom management & Low & 155 & 9.60 & 0.89 \\
\hline & & Moderate & 258 & 10.017 & 1.59 \\
\hline & & High & 537 & 10.021 & 1.67 \\
\hline & & Total & 600 & 10.016 & 1.66 \\
\hline \multirow[t]{4}{*}{4.} & Evaluation of students & Low & 185 & 9.20 & 1.10 \\
\hline & & Moderate & 258 & 10.74 & 2.50 \\
\hline & & High & 157 & 10.612 & 2.28 \\
\hline & & Total & 600 & 10.613 & 2.29 \\
\hline \multirow[t]{4}{*}{5.} & Learning motivation & Low & 185 & 9.20 & 1.10 \\
\hline & & Moderate & 258 & 9.81 & 1.47 \\
\hline & & High & 157 & 9.87 & 1.60 \\
\hline & & Total & 600 & 9.86 & 1.58 \\
\hline \multirow[t]{4}{*}{6.} & Supervision of co- & Low & 185 & 9.20 & 1.10 \\
\hline & Curricular activities & Moderate & 258 & 9.76 & 1.55 \\
\hline & & High & 157 & 9.83 & 1.65 \\
\hline & & Total & 600 & 9.82 & 1.64 \\
\hline \multirow[t]{4}{*}{7.} & Professional \& personal & Low & 185 & 11.20 & 4.60 \\
\hline & Qualities & Moderate & 258 & 10.00 & 1.80 \\
\hline & & High & 157 & 10.35 & 2.12 \\
\hline & & Total & 600 & 10.33 & 2.12 \\
\hline
\end{tabular}


Table 2: Result of Analysis of Variance of the influence of level of stress arising from workload on professional effectiveness.

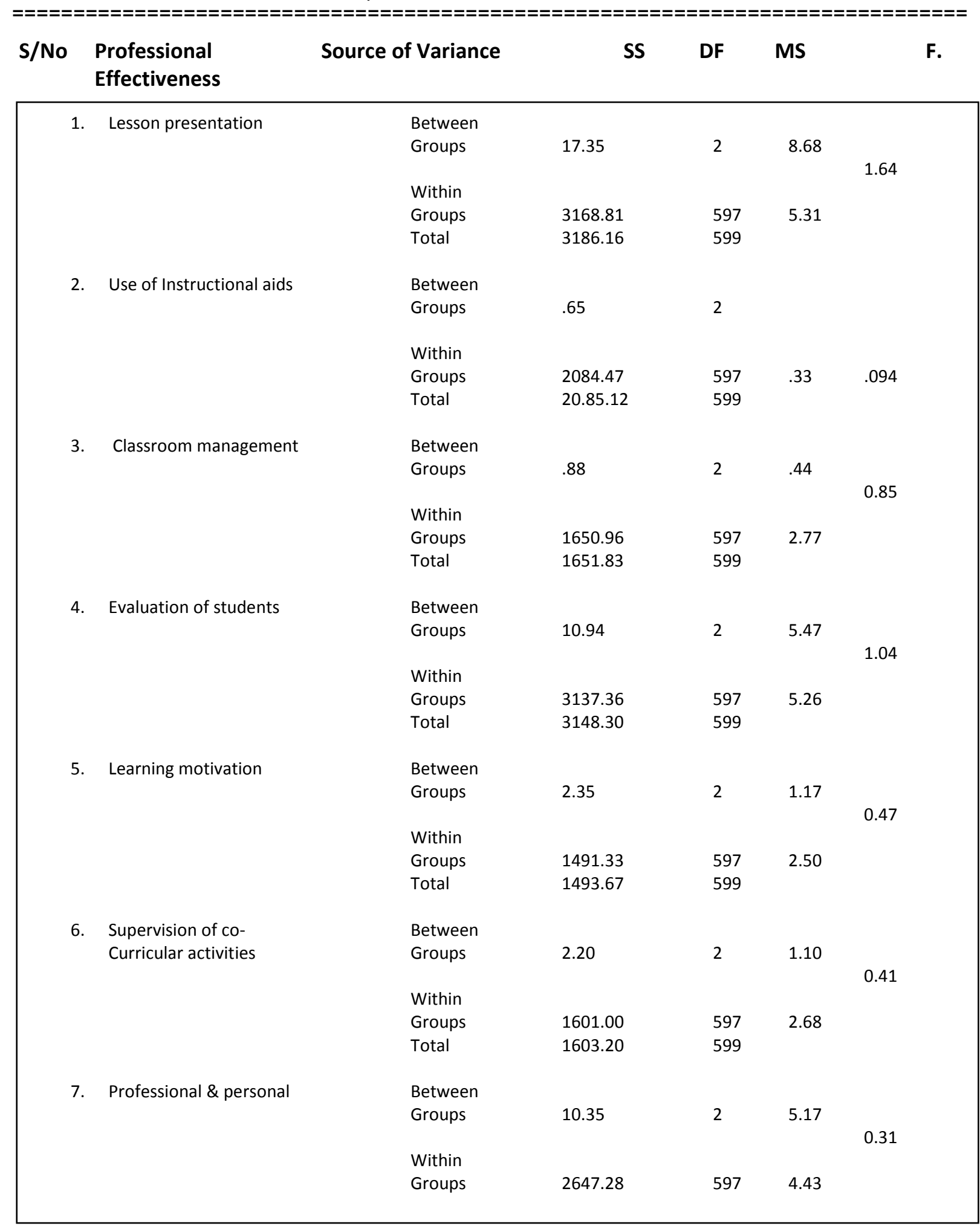

Critical

$F_{2}, 597=3.00$ at .05 level of significance 


\section{DISCUSSION}

The result of the research finding shows that stress arising from workload does not significantly influence the professional effectiveness of teachers. The finding is contrary to the findings of Orjiji (2000), who observed that overload and under load of job can generate feeling of hopelessness which may contribute towards lack of motivation, depression and inefficiency. The finding of also contradicts findings Denga and Ekpo (1994), Denga (1991), Ekpo(1993) who concluded that workload(overload and under load) is one of the major determinants of productivity and effectiveness. This finding also negates the views of Seigenthaler(1991)that workload affect worker performance.

The result is in line with the finding of the Australian Council for Educational Research (ACER) 2004 that mainly the Heads of departments (Managers) were clearly the group most affected by workload.

The plausible explanation may account for this finding .Firstly, is the fact that teachinglearning process involves a lot of energy sapping activities that may result to stress and the stakeholders in Education realizing this fact, have set aside some periods of the academic year for teachers and students to rest and relax both physically, mentally and emotionally to regain their lost vigor and strength that will enable them forge ahead in their pursuit for academic excellence. Rest, being one of the recommended management techniques to curb stress helps the body to recuperate from the psychological and physical depletion. With this, teachers are better adapted to cope with the stress that could have arisen from workload.

The second explanation is the fact that mainly the executives are affected by heavy workload as a result of the nature of their responsibilities, they also give in so much of their time to meet up with deadlines at the expense of their leisure. Some of them do not delegate powers and responsibilities to subordinates for mere fear that mistake might be made and decides to do almost everything. But for the teacher, it is a different ball game entirely, because the responsibilities in a secondary school setting are shared among the teachers and this had lessen the amount of work done by an individual teacher in such a way that effectiveness of the teachers can never be affected by workload.

\section{CONCLUSION}

The study indicated that the level of stress arising from workload has no significant impact on the effectiveness with which the teachers present their lessons, use instructional aids, manage their class, motivate students to learn, supervise cocurricular activities and on their professional/personal qualities. Workload in the school system is distributed among all the teachers in such a way that the work done by an individual teacher may not lead to stress and subsequent job ineffectiveness.

\section{RECOMMENDATIONS}

Management of industrial and organizational settings should adopt the secondary school system of sharing responsibilities among their workers and learn to delegate duties in order to reduce work done by an individual worker. Where the work done by a worker is observed to be on the high side, more workers should be employed.

\section{REFERENCES}

Amalu, M. N., Ajake, U and Ihejiamaizu, C., 2012. Stress from Role Conflict: Consequences for Professional effectiveness of Secondary School Teachers in Cross River State, Nigeria. Global Journal of Educational Research 11, (1): 37-47.

Arnold, H. J and Feldman, D., 1986. Organizational behavior. New York McGraw Hill.

Bassey, P., Bisong, N., Ubi, I and Isangedighi, A. J., 2011. Comparartive Job Performance Effectiveness of Teachers in Public and Private Secondary Schools in Cross River State, Nigeria. Annals of ModernEducation 3, (1): 54-60.

Bisong, J. O., 1996. Philosophy of education in Nigeria. Unpublished paper. University of Calabar, Calabar

Bryan, W and Kelly, L., 1984. Burnout in Nursing Education. Journal of Nursing Education, 21, (4): 29-34

Burry, R and Philip, C., 1991. How Faculty Members Spend Their Time. Nursing Outlook, 23 (3): 140-145 
Debra, E., 1995. Attributes of a Profession. Social work 3, (11): 45-55

Denga, D.I., 1991. Human behavior at work; Organizational behavior Calabar: Educational publishers.

Denga, D I and Ekpo, T. N., 1994. Executive stress. Its rape and management. Calabar: Rapid Educational publishers.

Fadipe, J. O., 1998. Modern strategies of school plant maintenance. Ondo:NEPA

Ekpo, T. N., 1993. Female Teachers' Stress: Extent, Sources and Symptoms. Journal of Higher Education 1, (1): 7-14.

Federal Republic of Nigeria., 2004. National policy on education ( $\left.4^{\text {th }} \mathrm{Ed}\right)$ Lagos: NERDC Press

Harbegar, K and Lohrs, V., 1984. Guidelines for Faculty Workload. American Journal of Nursing, 79, (5): 902-904.

Isangedighi, A. J., 2000 Teacher Professional Commitment. Education for Today 1, (1): 81-89.

Ivowi, U. M. O., 1986. Improving Teacher Education Programme in Nigeria. Presidential Address to the $2^{\text {nd }}$ Annual symposium of the Lagos Chapter of the Curriculum Organization of Nigeria held at the Faculty of Education, University of Lagos. 18th-19th December.

Martin, G. N., Carlson, N. R and Buskist, W., 2007. Psychology ( $3^{\text {rd }}$ Ed) England: Pearson Education Limited

Obanya, PAI., 2013. Quality teaching for quality learning in higher Education. Academic Staff Work shop at University of Calabar, Calabar, $12^{\text {th }}-13^{\text {th }}$ February, 2013.

Okute, A. L and Chukwurah, C. C., 2011. Rethinking Teacher Quality at the Higher Education Level: Need for ethical Reorientation towards Teacher effectiveness in Business Education. Annals of Modern Education. 3, (1): 98107.
Orjiji, M. C., 2000. Women in Stress. Nursing Perspective 14, (3): 23-25.

Tiji, T., 2000. Workplace Stress and Indication of Coronary Heart Disease Risk. Academic of Management Journal. 9(1):686-688. 